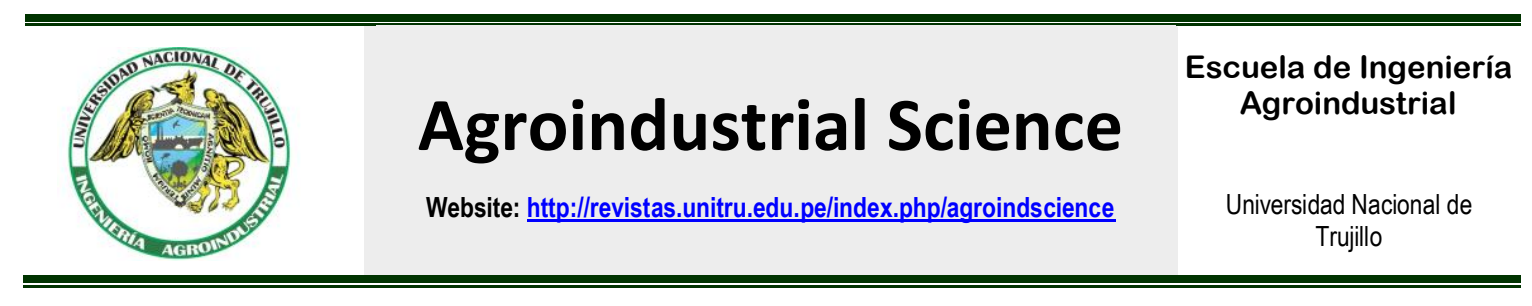

\title{
Lyophilized inchicapi: organoleptic, chemical and microbiological characteristic
}

Inchicapi liofilizado: características organolépticas, químicas y microbiológicas

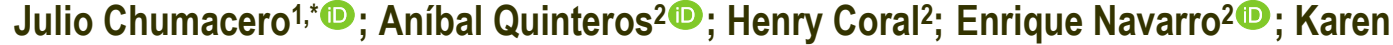 \\ Documet $^{2}$; Patricia García ${ }^{3}$ \\ 1 Facultad de Ecología, Departamento Académico de Ciencias Ambientales y Sanitaria, Universidad Nacional San Martín, Tarapoto, \\ Perú. \\ 2 Facultad de Ingeniería Agroindustrial, Departamento Académico de Ingeniería Agroindustrial de la Universidad Nacional de San \\ Martín, Tarapoto, San Martín, Perú \\ ${ }^{3}$ Facultad de Ciencias Agrarias, Departamento Académico Agrosilvo Pastoril de la Universidad Nacional de San Martín, Tarapoto, \\ San Martín, Perú.
}

\begin{abstract}
The objective of this research study was to develop a traditional and innovative food product such as lyophilized dehydrated inchicapi (peanut soup with cultural and culinary in value the Amazon community of Peru) by lyophilization, which allows the product's useful life to be extended, maintaining its physicochemical and sensory properties, and make it suitable for human consumption. These products underwent different treatment pressures of $0.05 \mathrm{mbar}, 0.1 \mathrm{mbar}$ and $0.16 \mathrm{mbar}$ and thicknesses of $8 \mathrm{~mm}$ and $10 \mathrm{~mm}$ were used, as appropriate. 30 days after the product was made, the organoleptic analysis determined that the T6 treatment (thickness of $10 \mathrm{~mm}$ and pressure $0.16 \mathrm{mbar}$ ) is the one with the best attributes with a score of 7.2. Also, the proximal chemical and microbiological analyzes gave as results: humidity: 5.13\%; fat: $39.0 \%$; fiber: $7.3 \%$; ash: $2.82 \%$; protein: $21.42 \%$; carbohydrates: $29.46 \%$ and energy: $554.5 \mathrm{kcal}$; evidencing good nutritional quality, a guarantee of product stability; as well as the presence of microorganisms below the standards allowed by Peruvian regulations. Concluding that the freeze-drying of the inchicapi allows us to develop a product that preserves the values of importance for the consumer.
\end{abstract}

Keywords: Inchicapi; instant soup; freeze-dried; organoleptic characteristic.

\section{RESUMEN}

El objetivo del presente estudio de investigación fue elaborar un producto alimenticio tradicional e innovador como inchicapi (sopa de maní con valor cultural y culinario en la comunidad amazónica del Perú) deshidratado por liofilización, que permita alargar la vida útil del producto, mantener sus propiedades fisicoquímicas y sensoriales, y se encuentren aptas para el consumo humano. Para la obtención de este producto se utilizaron tratamientos con presiones de 0,05 mbar, 0,1 mbar y 0,16 mbar y espesores de $8 \mathrm{~mm}$ y $10 \mathrm{~mm}$ según corresponda. A los 30 días de elaborado el producto, se procedió a realizar el análisis organoléptico que determino que el tratamiento T6 (de $10 \mathrm{~mm}$ y presión 0,16 mbar) es el que presenta mejores atributos con una puntuación de 7,2 . Asimismo, los análisis químico proximal y microbiológico dieron como resultados: humedad: 5,13\%; grasa: 39,0\%; fibra: 7,3\%; ceniza: 2,82\%; proteína: 21,42\%; carbohidratos: $29,46 \%$ y energía: 554,5 kcal; demostrando una buena calidad nutritiva, garantía de estabilidad del producto; así como presencia de microorganismos por debajo de los estándares permitidos por las normas peruanas. Concluyendo que la liofilización del inchicapi nos permite elaborar un producto que preserva los valores de importancia por parte del consumidor.

Palabras clave: Inchicapi.; sopa instantánea; liofilizado; características organolépticas.

\section{Introduction}

The traditional food products are part of a system in which utensils and background are integrated into the ways of life of producer families and their society. In a context where there is a growing distrust of the origin of traditional and typical foods; food products are essential to identify the origin and maintain the food culture (Meléndez and Cañez, 2009; Álvarez, 2002; Obregón y Obregón, 2019). The reason why its conservation is very important to keep these products in value (Sgarbi et al., 2015). 
The typical products incorporate local technical background developed with the experience acquired over time and related to the place to the cultivated varieties and the agricultural practices (Bruckmeier and Tovey, 2008). Local knowledge emerges over time as a synthesis of the intrinsic physical qualities of a locality and a socially constructed vision of the best methods of resource management (Van der Ploeg, 2010).

In Peru, due to its three great geographic regions (coast, mountains, and jungle) the existing cultural and culinary diversity; has a varied reach of typical and indigenous foods that are highly appreciated by native local people. Among these dishes is inchicapi, which is a soup made from peanuts, as the main ingredient, followed by a dose of corn and spices, widely consumed throughout the Amazon jungle (Caballero, 2016).

In the Department of San Martin, there is a great demand for typical meals, among them the inchicapi, which due to its exquisite taste, aroma and nutritional value, has expanded to the departments of Loreto, Madre de Dios, Ucayali and part of Huánuco (Tingo María). The name Inchicapi comes from the Quechua words "Inchic" means peanut, and "api" means soup. This dish is usually prepared for parties and special occasions (Del Águila, 2015; Caballero, 2016).

The preparation of this dish under traditional and ancestral conditions requires plenty of time for cooking, colliding with the times required for the preparation of pre-cooked foods that are consistent with lifestyles, arising from globalization and economic crisis, in which families have less time to prepare their food; due to the aforementioned, in recent years the consumption of dehydrated chicken or beef soups with noodles, vegetables, as well as vegetable and legume creams, porridges, among others, has increased (Reátegui, 2011).

One of the chain's strategies focuses on the valuation of a specific product, with the main objective of allowing the product with the cultural identity to travel to distant markets, without losing the link with its own culture. It' for that is important and necessary to maintain relationships between people who are abroad and acquired local customs to protect and enhance the product and local knowledge (Acampora et al., 2007). For this reason, adding value to the chain with preservation alternatives for these products is a challenge for the food industry.

Dehydration is one of the most remote means for food preservation, with the reduction of moisture content it is possible to preserve quality characteristics such as flavor, aroma and nutritional value, in addition to reducing the volume and weight of the product, which It makes the transport and storage of food products more efficient. To make use of dehydrated foods it is necessary to rehydrate them. The speed and ease in which this operation can be developed to mark the quality of the dehydrated product (Bello, 2000). As for drying, the efficiency of rehydration depends in large part on the type of product and its characteristics (size, geometry, the composition of the food, moisture content) (Acosta, 2009).

Lyophilization, also called cryo-dehydration or drying in the frozen state, is a food preservation technique that involves the reduction of its water activity (Rodríguez, 2002) through which the stability of the products is achieved. It is one of the most sophisticated systems to commercialize an organic liquid powder, allows almost complete dehydration without the increase in temperature that can vary the chemical composition and the curative activity of the final product (Wolfson, 1999).

The principle of lyophilization is to sublimate the ice of a frozen product. Sublimation should be carried out at very low pressures of at least 4,58 $\mathrm{mmHg}$ at $0{ }^{\circ} \mathrm{C}$, below the triple point of water. Since water is affected by the composition and biological structure of the food and by its concentration in solutes, the freezing temperature is usually established at the temperature of complete solidification in this case below $-10^{\circ} \mathrm{C}$. The operating pressure, on the other hand, must ensure that the crystallized water does not melt throughout the process (Rodriguez, 2002).

The purpose of this work was to evaluate some technological parameters related to the mass production of lyophilized inchicapi. For this, an analysis of the physical-chemical, microbiological and sensory characteristics of the finished product were carried out.

\section{Material and methods}

Raw Material

For the elaboration of the Inchicapi the following ingredients were used: peanut (Arachis hypogaea) of the variety "white tarapoto"; cornmeal (Zea mays), soft corn flour, "starchy" variety was used; garlic (Allium sativum L); coriander (Coriandrum sativum L.); cumin (Cuminum cymenum L.) and iodized salt.

Operations for the production of lyophilized inchicapi

Raw Material: coming from the supply market of Tarapoto city.

Selection and Classification: It was carried out manually, for which the kernels peanut in good condition were selected, as well as the other inputs (cilantro, garlic, cumin, yellow corn powder). 
Washing and Disinfected: Before the preparation of the inchicapi, the supplies were washed with $0.05 \%$ chlorine to remove foreign agents that may be harmful.

Blending: Crushing and disintegration of the peanuts together with the other ingredients that make up the base mixture of the product $(150 \mathrm{~g}$ of peanuts, $40 \mathrm{~g}$ of cornflour, $14 \mathrm{~g}$ of coriander, cumin, condiment curcumin (palillo), garlic and salt).

Freezing: The mixture of compact mass was conditioned on ice cubes to obtain a rectangular shape, first, they were weighed and coded; then freeze for 24 hours at $-21^{\circ} \mathrm{C}$.

Freeze-dried: After freezing, the mass in form of cubes was placed in the lyophilizer's vessels, previously weighed. The purpose of this operation was to dehydrate the product and reach its stability with pressures of $0.05 \mathrm{mbar} ; 0.1 \mathrm{mbar} ; 0.16 \mathrm{mbar}$, and thicknesses of the mass of $8 \mathrm{~mm}$ and $10 \mathrm{~mm}$. Packaging: finally, the samples were packed in polyethylene bags, hermetically sealed to ensure complete isolation of the environment around it.

Physicochemical analysis

To the starchy corn flour, peanut, lyophilized inchicapi, the percentage of protein, fiber, moisture, ash, total fat, and carbohydrates were determined, using the following methods.

- Determination of total proteins: The Kjeldahl method was used.

- Determination of fiber: It was carried out by the Henneberg method by Acid-Alkaline hydrolysis.

- Determination of humidity: By the drying method in an oven at $105^{\circ} \mathrm{C}$ until constant weight.

- Determination of ashes: By incineration of the sample in muffle at $550^{\circ} \mathrm{C}$ for 24 hours.

- Determination of total fat: It was carried out by the Soxhlet method using petroleum ether as a solvent.

- Determination of carbohydrates.

\section{Microbiological analysis}

The microbiological analyzes were carried out to ensure the innocuousness and good manufacturing practices of the lyophilized food. An analysis of Mesophilic Aerobics, Coliforms, Bacillus cereus, Salmonella sp, according to Peruvian Health Technical Standards.

\section{Experimental design}

For the selection of the best treatment of lyophilized inchicapi, a completely randomized block design (DBA) was used. The results were analyzed using a variance analysis table (ANOVA) with a level of significance of $5 \%$ and significant differences between the samples, using the Tukey test.

\section{Results and Discussion}

\section{Physicochemical analysis of raw materials and supplies}

Table 1 shows the results obtained from the proximal chemical analyzes of the raw peanut kernel, starchy cornflour, and inchicapi mass.

Regarding the peanut kernel, $6.73 \%$ moisture was obtained, a value lower than that reported by MINSA (2009) and Collazo et al. (2000) of 7.3\%. A variation that is possibly given by the place of origin, type of soil; while the fat content was 49.43\%; higher value found by MINSA (2009), which was $48.2 \%$. Similarly, the fiber content is $6.89 \%$, ash $2.24 \%$, protein $25.44 \%$, and carbohydrates were $9.28 \%$.

In starchy corn flour, the proximal chemical analysis indicated that the moisture content was $11.84 \% ; 6.67 \%$ protein and $69.22 \%$ carbohydrates, these values are slightly lower than those reported by MINSA (2009) and FAO (2001), however, these values may be due to the variety and the type of analysis performed.

Table 1

Physical-chemical characteristics of peanut, cornmeal and inchicapi mass

\begin{tabular}{lccc}
\hline Components & Peanut (Arachis hypogaea L.) & Starchy cornmeal & Inchicapi mass \\
\hline Moisture (\%) & 6.73 & 11.84 & 73.73 \\
Oil and fats (\%) & 49.43 & 6.87 & 42.5 \\
Fiber (\%) & 6.89 & 3.68 & 3.1 \\
Ashes (\%) & 2.24 & 1.72 & 1.5 \\
Protein (\%) & 25.44 & 6.67 & 23.5 \\
Carbohydrates (\%) & 9.28 & 69.22 & 29.5 \\
Energy (kcal) & 583.80 & 365.4 & 594.1 \\
\hline
\end{tabular}


The fat content was $6.87 \%, 3.68 \%$ fiber, ashes $1.72 \%$. Likewise, the analyzes carried out on the mass of the inchicapi reported a percentage of moisture of $73.73 \%$, product of the mixture of the inputs (peanuts, cornflour, broad coriander, yellow garlic, and salt) and the addition of water to homogenize our mass to then lyophilize it. Regarding the other analyzes, $42.5 \%$ were obtained in terms of fat, $3.1 \%$ in fibers, $1.5 \%$ in ashes, $23.5 \%$ in proteins, $29.5 \%$ in carbohydrates and energy $594.1 \mathrm{kcal}$ (Table 1).

\section{Results of the sensory tests formulated to lyophilized inchicapi}

To the different treatments in terms of pressure (0.05 mbar, 0.1 mbar and $0.16 \mathrm{mbar}$ ) and thickness $(8 \mathrm{~mm}$ and $10 \mathrm{~mm})$, the same lyophilization time (10 hours) and freezing of the product $\left(24\right.$ hours at $-21^{\circ} \mathrm{C}$ ) was applied. Using an unqualified panel, the attributes of aroma, color, flavor, and texture were evaluated. The results were analyzed through variance analysis and Tukey test to determine the comparison of the values in each attribute.

The variance analysis results based on taste showed that there is a significant difference between treatments at $0.05 \%$. As for the aroma variable, there is a significant difference depending on the panelists, thickness, pressure and the interaction of thickness with pressure. However, according to the results shown in Table 2 , the average Tukey test at $5 \%$ between treatments, there is no difference in terms of aroma for the applied treatments. The treatments T5 (7.3) and T6 (7.2) present better results with a degree of acceptance I like moderately, so we could adjust the pressures according to the energy expenditure to lyophilize since we obtain a quality product that also preserves its organoleptic properties. Similarly, the statistical analysis of the color attribute, without evidence of significant differences for the color attributes. As shown in the table, the values are in an average range, indicating that there is no difference in color and that the different lyophilized products show great acceptance by the panelists. The treatment with the best evaluation is T4, T5, and T6, which is found in the assessment of likes moderately.

As it affects the flavor variable, the analysis of variance at $95 \%$, indicates that there is a significant difference in terms of panelists and thickness, but according to the results of the Tukey test, see Table 2, all values of the different treatments are in the degree of acceptance I like moderately, in this way it allows us to explain the absence of effects on the variable of pressures and thickness since the product maintains the characteristic flavor of inchicapi.

Finally, regarding the texture, it was observed that there was a significant difference in the lyophilized inchicapi at different thicknesses and pressures; which may be explained by the high compressions in raw material, modify its surface and promote the diffusion of water at speeds typical of these combinations (Guo et al., 2012); It was determined in the analysis of the Tukey test (see Table 3) that the $T 6$ reported a higher degree of acceptance to the others with an average of I like it a lot, making it the best sample, these data are according to the S.A.S.

When the results were evaluated, it can be inferred that there are differences in the texture of the lyophilized product, giving us to understand that the best sample that the panelists prefer is the T6, which is why we take it as the best sample for our final lyophilized product. However, the results obtained from the analyzes carried out on the different treatments, show that the flavor, aroma, color, and texture in general, maintain the characteristics similar to the traditionally marketed product (Duan et al., 2010; Orrego, 2008).

Table 2

Tukey test at $5 \%$ for sensory analysis of aroma, flavor, and color in formulated inchicapi treatments

\begin{tabular}{clcccccc}
\hline & \multicolumn{2}{c}{ Treatment } & \multicolumn{2}{c}{ Aroma } & \multicolumn{2}{c}{ Flavor } & \multicolumn{2}{c}{ Color } \\
\hline Code & \multicolumn{1}{c}{ Description } & Averag & Rank & Average & Rank & Average & Rank \\
\hline $\mathrm{T}_{1}$ & Thickness $=8 \mathrm{~mm}$ y Pressure $=0.05 \mathrm{mbar}$ & 6.8 & $\mathrm{~A}$ & 6.6 & $\mathrm{~A}$ & 5.5 & $\mathrm{~A}$ \\
$\mathrm{~T}_{2}$ & Thickness $=8 \mathrm{~mm}$ y Pressure $=0.1 \mathrm{mbar}$ & 7.0 & $\mathrm{~A}$ & 6.9 & $\mathrm{~A}$ & 5.7 & $\mathrm{~A}$ \\
$\mathrm{~T}_{3}$ & Thickness $=8 \mathrm{~mm}$ y Pressure $=0.16 \mathrm{mbar}$ & 6.5 & $\mathrm{~A}$ & 62 & $\mathrm{~A}$ & 5.5 & $\mathrm{~A}$ \\
$\mathrm{~T}_{4}$ & Thickness $=10 \mathrm{~mm}$ y Pressure $=0.05 \mathrm{mbar}$ & 6.7 & $\mathrm{~A}$ & 6.8 & $\mathrm{~A}$ & 6.7 & $\mathrm{~A}$ \\
$\mathrm{~T}_{5}$ & Thickness $=10 \mathrm{~mm}$ y Pressure $=0.1 \mathrm{mbar}$ & 7.3 & $\mathrm{~A}$ & 6.9 & $\mathrm{~A}$ & 6.7 & $\mathrm{~A}$ \\
$\mathrm{~T}_{6}$ & Thickness $=10 \mathrm{~mm}$ y Pressure $=0.16 \mathrm{mbar}$ & 7.2 & $\mathrm{~A}$ & 6.9 & $\mathrm{~A}$ & 6.8 & $\mathrm{~A}$ \\
\hline
\end{tabular}


Table 3

Tukey test at $5 \%$ for sensory analysis of texture

\begin{tabular}{lclll}
\hline $\begin{array}{l}\text { Treat- } \\
\text { ment }\end{array}$ & Average & Rank & Rank & Rank \\
\hline $\mathrm{T}_{6}$ & 7.4 & $\mathrm{~A}$ & & \\
$\mathrm{~T}_{4}$ & 7.0 & $\mathrm{~A}$ & $\mathrm{~B}$ & \\
$\mathrm{~T}_{2}$ & 6.5 & $\mathrm{~A}$ & $\mathrm{~B}$ & $\mathrm{C}$ \\
$\mathrm{T}_{5}$ & 6.3 & $\mathrm{~A}$ & $\mathrm{~B}$ & $\mathrm{C}$ \\
$\mathrm{T}_{1}$ & 5.5 & $\mathrm{~A}$ & $\mathrm{~B}$ & $\mathrm{C}$ \\
$\mathrm{T}_{3}$ & 5.4 & $\mathrm{~A}$ & & $\mathrm{C}$ \\
\hline
\end{tabular}

\section{Physicochemical evaluation of lyophilized inchicapi}

Table 4 shows the results of the lyophilized physical-chemical characterization of the lyophilized corresponding to the pressure of $16 \mathrm{mbar}$ and thickness of $10 \mathrm{~mm}$, where there is a humidity gain due to the container used to store it.

Table 4

Proximal chemical analysis of lyophilized inchicapi expressed as a percentage

\begin{tabular}{lccc}
\hline \multirow{2}{*}{ Analysis (\%) } & \multicolumn{3}{c}{ Storage days } \\
\cline { 2 - 4 } & 0 & 15 & 30 \\
\hline Moisture (\%) & 3.05 & 3.67 & 5.13 \\
Fats (\%) & 405 & 38.5 & 39.0 \\
Fiber (\%) & 5.1 & 6.5 & 7.3 \\
Ashes (\%) & 1.4 & 1.2 & 2.82 \\
Protein (\%) & 22.6 & 21.5 & 21.42 \\
Carbohydrates (\%) & 30.4 & 32.3 & 29.46 \\
Energy (kcal) & 576.5 & 561.7 & 554.5 \\
\hline
\end{tabular}

\section{Microbiological analysis}

The microbiological analyzes performed on the final product were made to determine the presence of groups and concentrations of microorganisms that could damage or alter the quality of the product. The lyophilized product is under the acceptable limits for the consumption according to NTS No. 071 MINSA/DIGESA-V.01 (MINSA, 2008) (Table 5) for dehydrated products (freeze-dried, concentrates, mixtures) for instant use, which allows the reduction of probable microbiological contamination and extends their shelf life (Muñoz-López et al., 2018).

Table 5

Microbiological analysis of the lyophilized instant drink based on green plantain with milk and sugar

\begin{tabular}{lcc}
\hline Determinations & Permitted & Results \\
\hline Numeration E. Coli (UFC/g) & $10^{2}$ & 9.3 \\
Bacillus cereus (UFC/g) & $10^{3}$ & $<100$ \\
Salmonella sp. on $25 \mathrm{~g}$ & --- & Absence \\
\hline
\end{tabular}

\section{Conclusions}

The results obtained during the experimental tests of this research showed that the optimal treatment to make lyophilized inchicapi is given by freezing temperature $\left(-21^{\circ} \mathrm{C}\right)$; lyophilization pressure $(0.16$ mbar), with a thickness of $(10 \mathrm{~mm})$, during a lyophilization time of (10 hours). This freeze-dried product maintains the characteristic attributes of the traditional dish and allows compliance with the quality parameters present in Peruvian standards.

\section{ORCID}

J. Chumacero $\mathbb{D}_{\text {https://orcid.org/0000-0002-1116-9587 }}$
A. Quinteros $\mathbb{D}_{\text {https://orcid.org/0000-0002-4631-5089 }}$
E. Navarro $\mathbb{D}_{\text {https://orcid.org/0000-0002-9595-8830 }}$
K. Documet $\mathbb{D}_{\text {https://orcid.org/0000-0001-9545-7561 }}$
P. García $\mathbb{D}_{\text {https://orcid.org/0000-0003-3490-1977 }}$

\section{References}

Álvarez, M. 2002. El gusto es nuestro. Modelos alimentarios y políticas de patrimonialización" en Conferencia dictada en la sesión Patrimonio, culturas nacionales y turismo del II Congreso Internacional Cultura y desarrollo, La Habana.

Acampora, T.; Fonte, M. 2007. Productos típicos, estrategias de desarrollo rural y conocimiento local. Revista Opera 7: 191-212.

Acosta, W.D. 2009. Evaluación del Proceso de Rehidratación del Liofilizado de Aguacate Criollo (Persea americana Mill. Variedad Drimifolya) Mediante Análisis de Imágenes. México D.F.

Bello, G.J. 2000. Ciencia Bromatológica En: principios generales de alimentos, 1era Ed. pp 249-257, 441-447. España.

Bruckmeier, K.; Tovey, H. 2008. Dinámicas del conocimiento, identidad territorial y desarrollo rural sustentable en la unión europea. Revista Opera 7: 85-106

Caballero, M. 2016. Parámetros tecnológicos para la elaboración de sopa deshidratada tipo inchicapi de Gallus gallus domesticus (gallina). Tesis para obtener el título de Ingeniero. Facultad de Industrias Alimentarias. Universidad Nacional de la Amazonía Peruana, Perú

Collazo, C.; White, P.; White, H.; Viñas, E.; Alvistur, E.; Urquieta, R.; Vásquez, J.; Días,C.;Quiroz, A.; Roca, A.; Hegsted, M.; Brandfield, R. 1993. La Composición de los Alimentos de Mayor Consumo en el Perú. 6ta Edición, Lima- Perú.

Del Águila, C. 2015. Estudio del arte para la elaboración de sopas deshidratadas con materias primas de la región. Memoria descriptiva para optar el título profesional. Facultad de ingeniería en industrias alimentarias. Universidad Nacional de la Amazonía. Iquitos, Perú.

Duan, X.; Zhang, M.; Mujumar, A.; Wang, R. 2010. Trends in microwave-assisted freeze drying of foods. Drying Technology 28(4): $27-44$

FAO. 2001. Organización de las Naciones Unidas para la Agricultura y la Alimentación. 2001. El maíz en la nutrición humana. Código FAO: 86 AGRIS S01.

Guo, X.; Han, D.; Xi, H.; Rao, L.; Liao, X.; Hu, X.; Wu, J. 2012. Extraction of pectin from navel orange peel assisted by ultrahigh pressure, microwave or traditional heating: a comparison. Carbohydr. Polym. 88: 441-448.

Meléndez, J.; Cañez, G.2009. La cocina tradicional regional como un elemento de identidad y desarrollo local: el caso de San Pedro El Saucito, Sonora, México. Estudios sociales 17: 181204.

Ministerio de Salud del Perú - MINSA. 2008. Resolución Ministerial $\mathrm{N}^{\circ}$ 591-2008/SA/DM que aprueba la NTS $\mathrm{N}^{\circ}$ 071MINSA/DIGESA-V.01 Norma Sanitaria que establece los criterios microbiológicos de calidad sanitaria e inocuidad para los alimentos y bebidas de consumo humano. 
Ministerio de Salud del Perú - MINSA. 2009. Tablas Peruanas de Composición de Alimentos. Centro Nacional de Alimentación y Nutrición Instituto Nacional de Salud Lima- Perú.

Muñoz-López, C.; Urrea-García, G.; Jiménez-Fernández, M. Rodríguez-Jiménes, G.; Luna-Solano, G. 2018. Efecto de las condiciones de liofilización en propiedades fisicoquímicas, contenido de pectina y capacidad de rehidratación de rodajas de ciruela (Spondias purpurea L.). Agrociencia 52(1): 1-13.

Obregón, P.; Obregón, A. 2019. Obtención de un alimento liofilizado a base de maracuyá (Passiflora edulis) y camu camu (Myrciaria dubia). Journal of Agro-Industry Sciences 1: 17-24.

Orrego, C. 2008. Correlación y liofilización de alimentos. Edit. Artes Gráficas Tizán. Universidad Nacional de Colombia. Pp 172
Reátegui, M. 2011. Procesos físicos de conservación de alimentos. Lima-Perú. Primera Edición. Universidad de San Martín de Porres, Perú.

Rodríguez, S.; Aguado, A.; Cañizares, C.; López, P.; Santos, I.; Serrano, G. 2002. Ingeniería de la Industria Alimentaria. Operaciones de Conservación de Alimentos. Madrid, España. Editorial Síntesis S.A.

Sgarbi, S.J.; Menasche, R. 2015. Valorização de produtos alimentares tradicionais: os usos das indicações geográficas no contexto brasileiros. Cuadernos de Desarrollo Rural 12(75): 11-31.

Van der Ploeg, J. 2010. The Food Crisis, Industrialized Farming and the Imperial Regime. Journal of Agrarian Change 10(1): 98-106.

Wolfson, D. 1999. Probiotic primer. Natural Remedies. Nutrition Science News. Disponible en: http://www.NewHope.com 